\title{
ENSURING THE HUMAN RIGHTS AND FREEDOMS IN THE CONTEXT OF THE PANDEMIC COVID-19
}

GARANTIZAR LOS DERECHOS HUMANOS Y LAS LIBERTADES EN EL CONTEXTO DE LA PANDEMIA COVID-19

\section{Serhii Kivalov*}

\begin{abstract}
The study is devoted to the establishment of the current state of ensuring of human rights and freedoms in Ukraine while counteracting the spread of the Covid-19 pandemic taking into account the institutional and legal basis of the quarantine regime, transformations of ensuring of human rights and freedoms and the rights of participants in administrative procedures. Close attention is drawn to the impossibility of restricting human rights and freedoms that go beyond the goals of Covid-19 dissemination. In carrying out this study, general philosophical and special methods of scientific knowledge were used, namely the methods of: system analysis, dialectical, formal-logical and structural-functional, as well as some empirical methods. The practical significance of the study is that its results are relevant for domestic legislators and entities that carry out public administration in the field of health care against the background of updating trends in the response to the Covid-19 pandemic. A number of measures have been proposed to develop a strategy to counter the spread of the Covid-19 pandemic; creation of subjects of public administration, the competence of which will include ensuring the state policy in the field of ensuring the proper condition and maintaining the mental health of the
\end{abstract}

\footnotetext{
* Doctor of Legal Science. Academician full member of the National Academy of Law of Ukraine and National Academy of Pedagogical Sciences of Ukraine. Head of the Southern Regional Center National Academy of Law Sciences of Ukraine. Honored Lawyer of Ukraine. President of the National University "Odessa Law Academy". Professor of Department of administrative and financial law at National University "Odessa Law Academy” (Ukraine). ORCID: 0000-0002-4651-1805. kivsv15@gmail.com
} 
population; implementation of the concept of electronic justice (e-court) as the only possible mechanism to ensure effective protection of the rights, freedoms, and interests of man and citizen in the face of the Covid-19 pandemic.

Keywords: Mechanisms for Ensuring Rights, Quarantine Regime, Public Policies, Covid-19 Pandemic, Human Rights and Freedoms

Resumen: El estudio analiza cuál es el estado actual de las garantías de los derechos humanos y las libertades en Ucrania, y cómo se contrarresta la propagación de la pandemia de Covid-19, teniendo en cuenta la base institucional y legal de la cuarentena, las transformaciones para garantizar los derechos y los derechos de los participantes en los procedimientos administrativos. Se destaca la imposibilidad de restringir los derechos humanos que van más allá de los objetivos de la difusión de Covid-19. La investigación se localiza en Ucrania, aunque tiene perspectivas de un mayor desarrollo y se realiza con métodos filosóficos, a saber, los métodos de análisis de sistemas, dialéctico, formal-lógico y estructural-funcional, así como algunos métodos empíricos. Los resultados del estudio son relevantes para los legisladores nacionales y las entidades que llevan a cabo la administración pública en el campo de la atención médica, en el contexto de las tendencias de actualización en la respuesta a la pandemia de Covid-19. Se han propuesto varias medidas para contrarrestar la propagación de la pandemia de Covid-19, como la determinación de temas de administración pública, cuya competencia incluirá garantizar la política estatal en el campo de garantizar la condición adecuada y mantener la salud mental de la población; así como la implementación de la justicia electrónica (e-court) como único mecanismo que garantiza la protección efectiva de los derechos, libertades e intereses del hombre y el ciudadano frente a la pandemia Covid-19.

Palabras clave: Garantías de derechos, régimen de cuarentena, políticas administrativas, pandemia Covid-19, derechos humanos y libertades

Summary. I. Introduction. II. Methodology. III. Results and discussion. III.1. Institutional-legal basis of the quarantine regime in Ukraine. III.2. Qualitative state and dynamics of changes in ensuring human rights and freedoms in the face of the Covid-19 pandemic. III.3. Transformation of the rights of participants in administrative procedures in the context of counteracting the pandemic Covid-19. III.4. Adaptation of forms of access to court and administering justice in the context of counteracting the Covid-19 pandemic. IV. Conclusions. References. 


\section{INTRODUCTION}

The health of the Ukrainian nation should be a priority for any administrative apparatus and this claim does not need special substantiation. In the context of counteracting the coronavirus infection pandemic in 2019 (hereinafter "Covid-19"), for the first time since the independence of the Ukrainian state, the administrative-legal mechanisms of the quarantine regime have been implemented in practice. Instead, the mechanisms for ensuring the rights and freedoms of man and citizen during the implementation of quarantine are characterized by casuistic tendencies of the inconsistency of the current situation with the model of proper public administration, they are trying to introduce in recent years.

The structure of the article covers parts of the text devoted to the study of empirical sources on a given topic, including regulations, statistical analysis and case-law. Normative acts studied in the article include the law of Ukraine, bylaws of the Cabinet of Ministers of Ukraine and other bodies of state power and local self-government, international normative legal acts. Statistics include official data on the number of people infected with COVID-19 in the world and in Ukraine. The court cases referred to in the article include cases of appeals against acts imposing restrictions on human rights in connection with quarantine. All this together allowed the author of the article to reach sound conclusions and offer his vision of the prospects for regulatory improvement of the studied relations.

The sphere of ensuring human and civil rights and freedoms as an object of administrative-legal regulation in the fight against the Covid-19 pandemic needs to rethink the mechanisms for ensuring the right to an adequate level of medical care, the right to liberty and security, the right to privacy, freedom of conscience and freedom assemblies, the right to education, protection against crime and protection of victims of crime, among others, what is confirmed by the recommendations of the Council of Europe (Council of Europe, 2020).

The negative features of governance in the field of ensuring the rights and freedoms of man and citizen during the fight against the Covid19 pandemic are, first of all, the lack of a clear algorithm for the use of public administration tools. This applies to the implementation of executive and administrative activities in various areas of public relations, the provision of administrative services, and administrative prosecution. At a time when the international community aims to address such global 
issues as ensuring the rights of man and citizen to receive health care services, which provides non-discriminatory access to a certain list of basic health services for health promotion, prevention, treatment, rehabilitation, and palliative care and safe, inexpensive, effective, and high-quality medicines and vaccines, while ensuring that these services are not linked to the financial situation (Political declaration of the high-level meeting on universal health coverage, 2019) and respect for human rights in the fight against a pandemic Covid-19, which provides for the possibility of any manifestations of discrimination, racism, and xenophobia (Commissioner for Human Rights in St. Petersburg, 2020), Ukraine is trying to reform the system of state administration into a system of public administration, as the latter is characterized by signs of prompt resolution of emerging problems and gaps in legal regulation.

The creation of proper conditions and procedures for the full and unrestricted realization of one's rights and legitimate institutional provision on human rights, including free legal assistance, is one of the main directions of the state policy of Ukraine in the field of human rights (Kivalov, 2019). The tools of public administration, which are aimed at ensuring human rights and freedoms in the face of the Covid-19 pandemic, cannot be formulated in isolation from the real problems of today.

At the same time, it should be noted that Ukraine is quite successful in counteracting the epidemic. In particular, on March 12, 2020, immediately after the World Health Organization declared the beginning of the Covid-19 pandemic, a strict quarantine was declared in our country.

Due to the fact that quarantine was declared literally after the appearance of the first cases of the disease, the incidence rate in Ukraine was and remains one of the lowest in Europe. Currently, there are 5 European countries with the highest incidence rates: Russia $(687,862)$, United Kingdom $(285,768)$, Spain $(251,789)$, Italy $(241,819)$ and Germany $(196,944)$. In Ukraine, which is the largest European country (including the occupied territories), the number of patients is currently 49,607 people (European Centre for Disease Prevention and Control, data collected between 6:00 and 10:00 CET, 2020).

Thus, it seems necessary to develop both a long-term concept of sustainable development of the system of administrative influence in the quarantine regime, and simultaneous monitoring of existing and emerging problems in the field of human rights and freedoms, taking into account current morbidity and economic indicators. 


\section{Methodology}

Even though the issue of ensuring human rights and freedoms in Ukraine in the face of the Covid-19 pandemic is currently extremely relevant, there is currently no comprehensive study aimed at theoretically understanding the impact of forced restrictive measures on changing key aspects of human rights and freedoms and the level of quality of public administration in general. A significant number of specialists in various aspects of social knowledge (legal, medical, social) are engaged in the study of public relations, which is now objectively determined by the existing feature of the Covid-19 pandemic; depending on this, there are different approaches to the directions of theoretical understanding of the regulation of these social relations and the search for consensus between public and private interests.

The theoretical basis of this study is knowledge of the available tools of public administration in the face of the Covid-19 pandemic, on the one hand, and their impact on the state of human and civil rights and freedoms, on the other.

Regarding the definition of public administration, this study is based on the position that public administration means the activities of public administration entities regulated by laws and legal acts, which is aimed at implementing laws and other regulations by adopting administrative decisions and the provision of statutory services. In general, the administrative and legal support of the quarantine regime is manifested in restrictive measures. Accordingly, the sphere of ensuring human rights and freedoms as a result of the implementation of these measures has undergone certain restrictions and deviations.

At the same time, it is insufficient to study the real trends of dangers that threaten humanity in the face of the Covid-19 pandemic. From this point of view, it is necessary to use a formal-dogmatic approach, in which the rule of law must create favorable conditions for the protection of human rights and freedoms through the functioning of effective governance and development in any field under any circumstances. The development of a holistic mechanism for ensuring human rights and freedoms in the context of counteracting the spread of the Covid-19 pandemic is possible only through a combination of the following determinants: legal, contained in national and international regulations aimed at regulating public relations in the field of health and introduction of a quarantine regime; management, which is formed depending on the tools used by public authorities to regulate public relations in the face of 
the spread of the Covid-19 pandemic; socio-cultural, which determines the state and limits of human rights and freedoms during the introduction of quarantine.

This article examines the globalization aspects of countering the Covid-19 pandemic as a systemic factor in reforming the management approach in Ukraine. To consistently cover the problem, separate substantive blocks have been identified that characterize a homogeneous group of social relations related to the features of the mechanism of human rights and freedoms, namely: institutional-legal principles of the quarantine regime in Ukraine, qualitative state and dynamics of changes in human rights and freedoms in the context of counteracting the Covid-19 pandemic, transformation of the rights of participants in administrative procedures, adaptation of forms of access to court and administration of justice.

\section{RESULTS AND DISCUSSION}

\section{III.1. Institutional-legal basis of the quarantine regime in Ukraine}

In Ukraine, the legal provision of health care is provided by Art. 49 of the Constitution of Ukraine and is defined through the right to health care, the right to medical care, and the right to health insurance. Health care is provided by state funding of relevant socio-economic, health, and health prevention programs. As for medical care, the state creates conditions for effective and accessible medical care for all citizens. Medical care is provided free of charge in state and municipal health care facilities. Also, the responsibilities of the state in the management of health include supporting the development of physical culture and sports,

ensuring the sanitary-epidemiological well-being of the population (Constitution of Ukraine, 1996).

To carry out its tasks, the state, represented by the authorized bodies, must take all necessary measures, including quarantine, if necessary. The legal regime of quarantine is a set of rules enshrined in legal norms, which determine the content of the legal regime of quarantine, the procedure for its introduction and termination, the peculiarities of public authorities and local governments, enterprises, institutions and organizations under conditions of quarantine, human rights and freedoms, as well as the rights and legitimate interests of legal entities and liability for violation or noncompliance with the requirements and measures of the legal regime of quarantine. 
The specificity of the quarantine as a kind of extreme situation is that the precondition for its introduction is the need confirmed by the central executive body, which ensures the formation of state health policy, to prevent the spread of particularly dangerous infectious diseases. The legal regime of quarantine reflects the set of established necessary preventive, anti-epidemic and other administrative measures, their executors and terms of implementation, temporary restrictions on the rights of individuals and legal entities, and additional responsibilities imposed on them, the grounds and procedure for mandatory self-isolation, stay of a person in an observatory (observation), hospitalization in temporary health care facilities (specialized hospitals) (On protection of the population from infectious diseases: Law of Ukraine, 2020).

It is important to note that the definition of the essence of quarantine in formalized national sources of law took place long before the practical need to apply regulations emerged. Thus, quarantine is defined as a set of administrative and health measures used to prevent the spread of particularly dangerous infectious diseases. The danger in the form of the Covid-19 pandemic has made significant adjustments to the regulatory framework for quarantine. Moreover, the existing institutional and legal gaps require the development and application of reformatted public administration tools.

The imposition of quarantine is marked by the adoption of the relevant decision of the Cabinet of Ministers of Ukraine of March 11, 2020 (On prevention of the spread on the territory of Ukraine of the acute respiratory disease Covid-19 caused by the coronavirus SARS-CoV-2, 2020). Among the administrative measures that have been introduced to prevent the spread of the Covid-19 pandemic are the following: a ban on visiting educational institutions by its recipients, a ban on holding mass events in which more than ten people participate; prohibition of activity of business entities, which provide for the reception of visitors (these include: catering establishments, shopping and entertainment centers, other entertainment establishments, fitness centers, cultural institutions, establishments of trade and consumer services), except in certain cases; prohibition of transportation in suburban, long-distance, intra-regional and inter-regional communication within the established limits; ban on transportation of passengers by subways and rail transport; introduction of electronic service for monitoring compliance with self-isolation and/or observation, among others.

Among the health measures implemented to prevent the spread of the Covid-19 pandemic, quarantine-restrictive measures not related to security and law enforcement measures should be singled out (International Health 
Regulations, 2005), namely: the establishment of mandatory and periodic preventive medical examinations of certain professions, industries, and organizations (On ensuring the sanitary and epidemic well-being of the population: Law of Ukraine, 1994); the obligation to observe and selfisolate persons who fall under the criteria set out in the quarantine decision; commitment to mandatory testing for Covid-19 under the standards of the Ministry of Health of patients receiving medical care in connection with the planned hospitalization activities (On establishing quarantine in order to prevent the spread of acute respiratory disease Covid-19 caused by coronavirus SARS-CoV-2 on the territory of Ukraine, and stages of mitigation of anti-epidemic measures, 2020); approval of clinical routes of patients at all levels of medical care; establishing special rules for medical examination and treatment of persons suspected of having Covid-19 (Organization of medical care for patients with coronavirus disease (Covid-19): Order of the Ministry of Health of Ukraine, 2020).

Each country, including Ukraine, should implement a comprehensive set of measures appropriate to its capabilities and situation to slow down virus transmission and reduce Covid-19-related mortality, with the ultimate goal of achieving and/or maintaining a stable level of virus transmission or the absence of new infections. Based on the model legislation (Updated strategy to combat Covid-19, 2020b), the strategy at the national level should reflect a comparison of measures to reduce direct mortality associated with Covid-19, indirect mortality associated with health system congestion and the interruption of other priority medical and social services, as well as the minimization of dangerous and long-term negative consequences for health and well-being due to the socio-economic effect of certain retaliatory measures.

Taking into account the above factors, Ukraine had three behaviors at the beginning of quarantine:

Figure 1. The models of the quarantine regimes
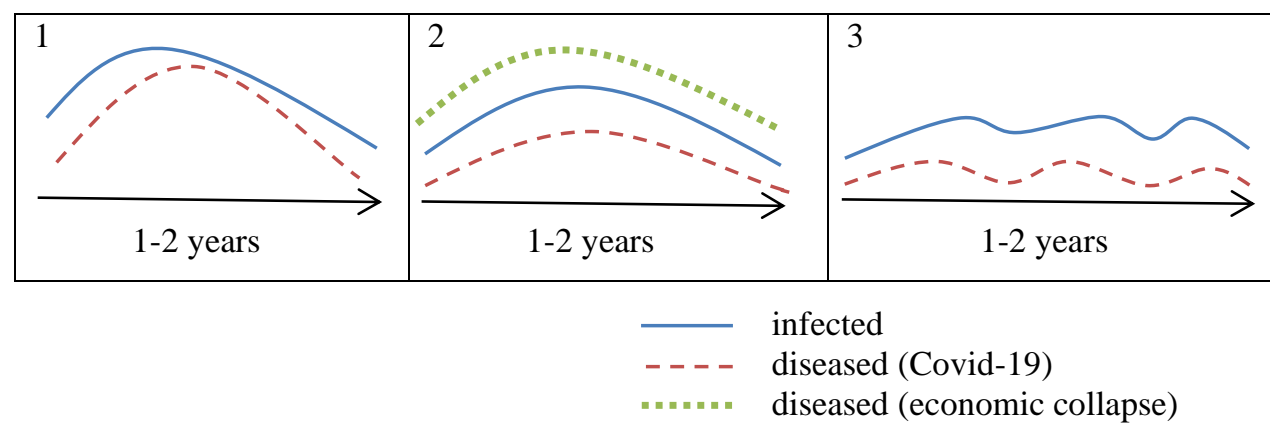
1. Creation of group immunity due to the complete abolition of quarantine (medieval scenario). The economy is not negatively affected. A large number of infected people who are excluded from economic processes. The death toll could be critical, leading to instability in the country.

2. Quarantine until the possibility of vaccination. Significantly limited economy and a minimum of infected and deaths from Covid-19. Critical economic downturn, unemployment, severe social crisis. A large number of deaths from economic causes.

3. Quarantine measures are minimal until the moment when: more than $50 \%$ of beds in health care facilities designated for hospitalization of patients with Covid-19 are overloaded; during the last seven days, the average number of PCR and ELISA tests is less than 24 per 100 thousand; more than $11 \%$ is the detection rate of Covid-19 infections. In this case, strict quarantine is introduced.

Our state has chosen a model with strict quarantine, with a gradual transition to adaptive quarantine, because the objective state of the domestic health care system does not allow us to be sure that everyone who needs medical care will be able to receive it in full. At the same time, different models of quarantine were introduced in different countries of the world: in particular, in Belarus quarantine was not introduced at all, in Sweden and Great Britain restrictive measures in the early stages of the pandemic were minimal and were strengthened with increasing victims, while in most Eastern countries. In Europe, quarantine measures were strict from the beginning, as a result of which it was possible to curb the sharp spread of the virus. At the same time, Italy and Spain, which are currently or most affected by the Covid-19 coronavirus among other European countries, initially reacted to quarantine measures from above, but later, when the incidence reached thousands, imposed the most severe restrictive measures.

Thus, the model of coronavirus control chosen by Ukraine has yielded results, because even after the weakening of quarantine related to the need to rebuild the economy, the health care system is operating normally and the incidence rate is not critical. In particular, the average provision of hospitals in Ukraine is $77.3 \%$, and the average occupancy of hospitals does not exceed 16\% (Analytical panels and open data, 2020).

At the same time, the option chosen by the government to counter the pandemic inevitably affected the economic situation of the country in a negative sense, as economic activity within the country due to the 
restrictive measures during the period of strict quarantine was significantly reduced.

As a result, according to the forecasts of the National Bank of Ukraine, Ukraine in 2020 may face a decline in exports (-10\%), imports ($14.5 \%$ ), widening budget deficit (8\% of GDP) and rising unemployment (up to $9.5 \%$ ). According to the Government's forecast, real GDP will fall by $4.2 \%$ in 2020, $5 \%$ according to the National Bank of Ukraine, and $7.7 \%$ according to the IMF (Analytical panels and open data, 2020).

Therefore, it is important to emphasize that in order to effectively counter the pandemic, all public authorities and local governments must clearly perform their direct functions. In particular, executive and administrative activities in the field of ensuring a set of administrative and health measures used to prevent the spread of the Covid-19 pandemic are carried out by:

(i) the highest body of executive power: the Cabinet of Ministers of Ukraine (About the Cabinet of Ministers of Ukraine: Law of Ukraine, 2014);

(ii) public health authorities of national importance, which include: Ministry of Health of Ukraine (On approval of the Regulation on the Ministry of Health of Ukraine, 2015) which includes 16 departments and 5 sectors (Official website of the World Health Organization, 2020), The National Health Service of Ukraine, which is the central executive body, whose activities are directed and coordinated by the Cabinet of Ministers of Ukraine through the Minister of Health, which implements the state policy in the field of state financial guarantees of health care (Regulations on the National Health Service of Ukraine, 2017);

(iii) health care bodies of local significance, which include: local state administrations within the powers provided by law (On local state administrations: Law of Ukraine, 1999), village, settlement, city councils, and their executive bodies, as well as district and regional councils, which represent the common interests of territorial communities of villages, cities in the field of health care (On local self-government in Ukraine: Law of Ukraine, 1997).

(iv) health care institutions (legal entities of any form of ownership and organizational and legal form or its separate subdivision, providing medical care to the population based on the relevant license and professional activity of medical (pharmaceutical) workers (Fundamentals of Ukrainian legislation on health care: Law of Ukraine, 1993);

(v) public associations that act to preserve and restore physiological and psychological functions, optimal performance and social activity of human at the maximum biologically possible individual life expectancy in 
the face of the Covid-19 pandemic (On ensuring public participation in the formation and implementation of state policy: Resolution of the Cabinet of Ministers of Ukraine, 2010);

(vi) enterprises, institutions, and organizations, which act as subjects of delegated authority to counter the spread of the Covid-19 pandemic;

(vii) central executive bodies: the Ministry of Internal Affairs of Ukraine, the National Police and the National Guard of Ukraine as law enforcement agencies authorized to monitor compliance with quarantine legislation related to countering the spread of the Covid-19 pandemic (On establishing quarantine in order to prevent the spread of acute respiratory disease Covid-19 caused by coronavirus SARS-CoV-2 on the territory of Ukraine, and stages of mitigation of anti-epidemic measures, 2020).

Special attention should be paid to the challenges related to the problems of ensuring normal mental health, which are mediated by the implementation of quarantine measures (Official website of the World Health Organization, 2020a). The lack of consideration of global problems related to the mental health of the population leads to the fragmentation of the implementation of national public administration in this area. It is considered expedient to establish a Mental Health Support Service at the Ministry of Health of Ukraine, as a central executive body, whose activities are directed and coordinated by the Cabinet of Ministers of Ukraine through the Minister of Health, which implements the state policy in the field of ensuring the proper condition and maintenance of mental health.

\section{III.2. Qualitative state and dynamics of changes in ensuring human rights and freedoms in the face of the Covid-19 pandemic}

In Ukraine, the constitutional level stipulates that guarantees of human rights and freedoms determine the essence and content of state activity. The term "guarantee" (from the French "garantie," meaning "security; guarantee; a condition that provides something") in the adaptation to the protection of human rights means conditions, methods that ensure the full implementation and comprehensive protection of individual rights and freedoms. The system of guarantees for human rights in the face of the Covid-19 pandemic has changed the set of objective and subjective factors aimed at the practical realization of such universally recognized rights as: the right to prohibit torture and inhuman or degrading treatment or punishment; the right to health care; the right to medical care; the right to health insurance; the right to liberty and security and the right to a fair trial; the right to privacy, freedom of conscience, freedom of 
expression, freedom of assembly, etc. (Universal Declaration of Human Rights, 1948; Constitution of Ukraine, 1996).

The level of action taken in response to the current threat caused by coronavirus Covid-19 should be commensurate with the purpose of their implementation. Certain rights do not allow any deviation from the obligations to comply with them, for example, the right to life, the prohibition of slavery and forced labor, the principle of the inadmissibility of bringing a person to justice twice for the same offense.

The right to prohibit torture and inhuman or degrading treatment or punishment should take into account the specificities of its provision to persons deprived of their liberty in the context of the Covid-19 pandemic. Special attention should also be paid to persons detained in police stations, penitentiaries, detention centers for migrants, psychiatric hospitals, and social protection institutions, as well as in various newly established institutions or areas where people are quarantined in the context of the Covid-19 pandemic.

Restrictions on the right to privacy, freedom of conscience, freedom of expression, and freedom of assembly are acceptable only if they are established by law and are proportionate to the legitimate aim pursued, including health care. Significant restrictions on ordinary social activities, including access to public places of worship, public gatherings, weddings, and funerals, can inevitably lead to conflicting complaints about the above provisions. Although increased restrictions on the above rights may be fully justified during a crisis, severe criminal penalties are a matter of concern and should be subject to strict control. Exceptions should not lead to the overestimation of criminal means. A fair balance between coercion and prevention is the most appropriate (if not the only) way to ensure this group of human rights.

As for the right to the confidentiality of personal data, it is subject to certain restrictions in terms of tracking patients with Covid-19 and contact persons. This is indirect because access to and processing of personal data provides an opportunity to help contain and overcome the pandemic. Monitoring, tracking, and prediction are important elements of epidemic surveillance. At the same time, the obsessive potential of modern technology should not be left unchecked and unbalanced in the context of the need to respect privacy.

As for the right to liberty and security of person and the right to free movement and freedom of choice of residence (Constitution of Ukraine, 1996), it has undergone significant changes due to the imposition of several restrictive measures. At the same time, these administrative measures should be considered justified based on the provisions of the 
European Convention on Human Rights relating to health, such as Articles 5, 8, 9-11, etc. (Convention for the Protection of Human Rights and Fundamental Freedoms as amended by Protocols $\mathrm{n}^{\circ} 11$ and 14, 1950).

On the other hand, there is a view on the illegality of restricting the right to free movement. In this context, we can give an example of a court appeal against the decision of the Cabinet of Ministers of Ukraine on the introduction of quarantine in Ukraine. In particular, 22 lawsuits were filed in the District Administrative Court of Kyiv to declare the decision illegal and annul it (Legalhub, 2020).

Among other things, the plaintiffs emphasize the illegality of the ban on traveling with a group of more than two people, visiting parks, squares, recreation areas, and sports grounds, as well as being on the street without identity documents, citizenship or special status (Ukraine, Judicial Power, 2020).

It is unlikely that any of the lawsuits have a judicial perspective, especially since the quarantine has recently been relaxed, but the very fact that there is a precedent for appealing the government's quarantine decision is important.

It is worth noting that although a significant part of human rights has been subject to certain restrictions, the state has introduced several additional measures to ensure the human right to social protection and an adequate standard of living (Constitution of Ukraine, 1996). Among such measures it is necessary to allocate: definition of term of stay in leave without preservation of a salary for the period of quarantine separately from the general term of stay in such leave; exemption from value added tax of transactions on importation into the customs territory of Ukraine and / or transactions on supply in the customs territory of Ukraine of goods (including medicines, medical devices and/or medical equipment) necessary for the implementation of measures aimed at to prevent the occurrence and spread, localization and elimination of outbreaks, epidemics and pandemics Covid-19; preventing the cessation of housing subsidies for the period of quarantine or restrictive measures related to the spread of coronavirus disease; assignment of a housing subsidy for the next period for all households, without exception, that received a housing subsidy in the previous period, without their application; expanding the range of recipients of housing subsidies in connection with the establishment of quarantine or restrictive measures related to the spread of coronavirus disease; registration of the unemployed from the first day after submission by the job seeker of the application for granting the status of the unemployed, and appointment of the unemployment benefit from the first day after registration of the unemployed; suspension of the obligation 
to fulfill the main obligation, the fulfillment of which is secured by a mortgage, and prevention of foreclosure on the subject of the mortgage for the period of quarantine or restrictive measures related to the distribution of Covid-19, etc. (On amendments to certain legislative acts of Ukraine aimed at preventing the occurrence and spread of coronavirus disease (Covid-19), 2020).

\section{III.3. Transformation of the rights of participants in administrative procedures in the context of counteracting the pandemic Covid-19}

Adaptation to the conditions of counteraction to the Covid-19 pandemic has significantly affected the forms of the internal organization of public administration, primarily the use of tools and the implementation of administrative procedures. As a result, the procedure has changed, including entering the civil service, electronic declaration, administrative services, etc.

The change in the procedure for entering civil service positions was a suspension of the provisions of the Laws of Ukraine "On Civil Service" and "On Central Executive Bodies" in terms of competitions for civil service positions and appointment to civil service positions based on the results of the competition and cancellation of competitions in which the Commission on Senior Civil Service or the competition commission has not proposed candidates to determine the winner by the appointing entity or the head of the civil service and the competition, the results of which have not been made public (On Amendments to the Law of Ukraine "On the State Budget of Ukraine for 2020": Law of Ukraine, 2020). Due to this, the right of access to the civil service of persons who took part in such competitions was restricted. Instead, a new mechanism for selection for vacant civil service positions for the period of quarantine, established by the Cabinet of Ministers of Ukraine to prevent the spread of acute respiratory disease Covid-19 caused by coronavirus SARS-CoV-2, and within 30 days from the date of cancellation quarantine (Some issues of appointment to civil service positions for the period of quarantine established to prevent the spread of acute respiratory disease Covid-19 caused by coronavirus SARS-CoV-2 in Ukraine: Resolution of the Cabinet of Ministers of Ukraine, 2020).

This temporary mechanism for selecting vacant civil service positions during the quarantine period provides for two options: the first is to complete competitions in which the Senior Civil Service Commission or the Competition Commission proposes candidates to determine the winner-by interviewing candidates, including remotely by 
videoconference subject to technical feasibility and determination of the winner of the competition, the second - appointment to the position of civil service by concluding a contract, the term of which is set for the quarantine period and until the day of determining the subject of appointment or head of civil service under the law. And according to the terms of the Standard contract for civil service for the period of quarantine, established to prevent the spread of acute respiratory disease Covid-19 caused by coronavirus SARS-CoV-2 in Ukraine, the maximum period of a person in this civil service position is not more four months after the abolition of quarantine established by the Cabinet of Ministers of Ukraine (Some issues of appointment to civil service positions for the period of quarantine established to prevent the spread of acute respiratory disease Covid-19 caused by coronavirus SARS-CoV-2 in Ukraine: Resolution of the Cabinet of Ministers of Ukraine, 2020).

The main changes in the electronic declaration procedure are the postponement of the declaration by a declaring entity of a person authorized to perform state or local government functions until June 1 (as a general rule - by April 1 of the year) and release from liability for late submission of a declaration by a person authorized to execute functions of the state or local self-government or notification of significant changes in property status during the period of quarantine and restrictive measures (On the prevention of corruption: Law of Ukraine, 2014).

With the establishment of a quarantine regime by the Cabinet of Ministers of Ukraine, in order to prevent the spread of coronavirus disease (Covid-19), the number of administrative services provided through administrative service centers was limited to 19 administrative services. For comparison, it should be noted that the number of administrative services that are generally provided through the center of administrative services is 136 (Some issues of providing administrative services of executive bodies through the centers of providing administrative services: order of the Cabinet of Ministers of Ukraine, 2014). In this case, based on agreed decisions with the subjects of administrative services through the center of administrative services may be provided and other administrative services (About administrative services: Law of Ukraine, 2012). It is also important to note that the period of quarantine or restrictive measures related to the spread of coronavirus disease (Covid-19) has been suspended (On amendments to certain legislative acts of Ukraine aimed at preventing the occurrence and spread of coronavirus disease (Covid-19), 2020).

At the same time, it should be noted the rather rapid development of electronic administrative services: during the quarantine regime, the provision of electronic services was introduced or significantly improved, 
for example: the acquisition of unemployment status and registration of unemployment benefits (On the implementation of a pilot project on the registration, re-registration of the unemployed and the appointment of unemployment benefits in electronic form: Resolution of the Cabinet of Ministers of Ukraine, 2020); registration of the form of incapacity to work (On the peculiarities of maintaining the Electronic Register of sick leaves to ensure information interaction of the electronic health care system with the Electronic Register of sick leaves: the resolution of the Cabinet of Ministers of Ukraine, 2020); submission of documents for enrollment in educational institutions (On full general secondary education: Law of Ukraine, 2020) etc. At this time, work is actively underway to digitize the information contained in the relevant documents of the person, in particular: the passport of a citizen of Ukraine, the passport of a citizen of Ukraine for travel abroad (On the implementation of a pilot project on the use of electronic display of information contained in the passport of a citizen of Ukraine in the form of a card, and electronic display of information contained in the passport of a citizen of Ukraine for travel abroad: Cabinet of Ministers of Ukraine, 2020); driver's license (On the implementation of the pilot project on the use of electronic driver's license and electronic vehicle registration certificate: Resolution of the Cabinet of Ministers of Ukraine, 2019); electronic student tickets (On the implementation of an experimental project on the use of electronic student tickets: Resolution of the Cabinet of Ministers of Ukraine, 2019).

\section{III.4. Adaptation of forms of access to court and administering justice in the context of counteracting the Covid-19 pandemic}

Judicial protection of the rights, freedoms, and interests of man and citizen has been and remains the most effective and efficient way to protect violated rights, it is a key of the rule of law and is guaranteed by the Constitution of Ukraine and the Convention for the Protection of Human Rights and Fundamental Freedoms of November 4, 1950. Ukrainian judicial system appeared unprepared to respond to existing challenges, which led to the de facto suspension of court cases, both those that were already in court and cases on new lawsuits and thus made it impossible to effectively protect the rights, freedoms, and interests of man and citizen.

The concept of e-litigation (e-court) has proved its relevance and demand as never before. Postponement of the full-fledged launch of electronic litigation (Unified Judicial Information and Telecommunication System) under the provisions of the Procedural Codes (Administrative Procedure Code of Ukraine, Civil Procedure Code of Ukraine, Commercial 
Procedure Code of Ukraine), updated in 2017 (On amendments to the Commercial Procedural Code of Ukraine, the Civil Procedure Code of Ukraine, the Code of Administrative Procedure of Ukraine and other legislative acts: Law of Ukraine, 2017), primarily due to technical reasons, forced the legislator to hastily introduce mechanisms for remote litigation, at least through court hearings.

In the context of ensuring the right to a fair trial (Convention for the Protection of Human Rights and Fundamental Freedoms as amended by Protocols $\mathrm{n}^{\circ} 11$ and 14, 1950), the Council of Europe recommends that the Member States take into account that measures aimed at adapting forms of access to justice must be designed to be compatible with Article 6, litigation, family, and labor disputes, etc.). Prolonged police detention or delays in judicial review of detention may lead to violations of Article 5 of the Convention. States also have a common duty: to ensure that trials are based on the fundamental requirement of justice (e.g. equality of arms) and the presumption of innocence as well as do not take measures that could impede the independence of judges or courts (Council of Europe, 2020).

Thus, legislative changes have simplified the procedure for participation in court hearings by videoconference, in particular, the possibility of using their technical means, and extended the quarantine procedure, including the time to appeal to the court, filing applications on the merits, etc. (On amendments to some legislative acts of Ukraine aimed at providing additional social and economic guarantees in connection with the spread of coronavirus disease (Covid-19), 2020).

During the quarantine regime, the parties to the case may participate in the court hearing by videoconference outside the court premises using their technical means. Therefore, the possibility of applying these provisions is allowed only during the quarantine regime. In this case, the confirmation of persons involved in the case will be carried out in several ways: either with the use of electronic signature (electronic data attached by the signatory to other electronic data or logically associated with them and used by him as a signature (On electronic trust services: Law of Ukraine, 2017), or in the manner prescribed by law Of Ukraine "On the Unified State Demographic Register and documents confirming the citizenship of Ukraine, identity or special status" (in particular, documents proving the identity and citizenship of Ukraine-passport of a citizen of Ukraine; passport of a citizen of Ukraine to travel abroad; diplomatic passport of Ukraine, etc. and documents certifying the identity and confirming its special status-driver's license, permanent/temporary residence permit, migrant card, etc.), or in the manner prescribed by the State Judicial Administration of Ukraine. At the same time, the State 
Judicial Administration of Ukraine determines not so many participants of the case, as well as the procedure for technical support for participation in the court hearing by videoconference outside the court premises using (On amendments to the Procedure for working with technical means of videoconferencing during a court hearing in administrative, civil and commercial proceedings with the participation of the parties outside the courtroom: order of the State Judicial Administration of Ukraine, 2020).

The presented innovations partially managed to ensure justice in the quarantine regime and court hearings. However, a number of other issues remain unresolved, which deter the use of these norms and makes it impossible to effectively protect the rights, freedoms, and interests of individuals and legal entities. For example, videoconference hearings remain an additional way to participate in court hearings, initiated by the parties (application is submitted no later than five days before the court hearing), and the final decision is made by the presiding judge (provided the court has the appropriate technical possibility (availability of equipment and possibility of its use on a certain day and time)); risks of technical impossibility to participate in videoconference outside the courtroom, interruption of communication, etc. continues to be borne by the party of the case, who submits the relevant application, etc. In addition, the main method of identification, a party to the case, has an electronic signature, and the decision on the possibility of confirming the person with other documents is made by a judge, which allows restriction of the right of access to the court of persons who do not have an electronic signature.

The envisaged extension of the procedural terms for the period of quarantine established by the Cabinet of Ministers of Ukraine to prevent the spread of coronavirus disease has received a double focus in terms of ensuring the right of access to the court. On the one hand, this step is aimed at respecting the procedural rights of the parties to the case, and on the other - leads to the actual suspension of procedural deadlines and, as a result, the suspension of court proceedings. For example, in deciding to initiate proceedings, the court sets a time limit for filing a response to the claim for the defendant, and such time limit may not be less than the term of quarantine related to the prevention of coronavirus disease, which means that the calculation of the established procedural period will begin after the end of quarantine, in connection with which further consideration of the case is impossible. The identified problem is not solved by the introduction of an electronic court (including court hearings by videoconference), because the desire to ensure compliance with the rights of some participants in the case, automatically leads to ineffective implementation of the rights of others. 


\section{CONCLUSIONS}

1. The challenges that arose in the context of counteracting the Covid-19 pandemic led to a revision of approaches and mechanisms for the implementation of executive and administrative activities by public administration entities, certain aspects of administrative procedures, including entering the civil service, electronic declaration, administrative services.

2. The concept of e-justice (e-court), the only possible mechanism for ensuring effective protection of human rights, freedoms, and interests in the face of the Covid-19 pandemic, was finally approved as a priority goal.

3. In addition to the introduction of mechanisms for the remote administration of justice in Ukraine, procedural deadlines have been extended, which is a guarantee of the administration of justice in the face of limited social contacts; the submission of declarations by the subjects of declaration to the tax service has been postponed, the persons authorized to perform state or local government functions were released from liability for late submission of declarations or for violation of the notice period on significant changes in the property status of during quarantine and restrictive measures; during the quarantine regime, the provision of some electronic services was introduced or significantly improved.

Thus, despite the negative impact on various processes, it seems that any crisis, including the crisis caused by the consequences of the emergence and spread of Covid-19, provides opportunities for qualitative improvement of mechanisms for human and civil rights and freedoms, updating and universalization of tools of public administration.

4. Despite the above, it seems that any crisis, including the crisis caused by the consequences of the emergence and spread of Covid-19, provides opportunities for qualitative improvement of mechanisms for human rights and freedoms, updating and universalization of tools of public administration.

5. It is proposed to use a comprehensive approach to human rights in the face of the Covid-19 pandemic, which is based on globalization. As a result, the following measures are proposed: development of a Strategy to counteract the spread of the Covid-19 pandemic; creation of the Mental Health Support Service, which will be responsible for the implementation of state policy in the field of ensuring the proper condition and maintaining the mental health of the population; elaboration of the Unified Concept of Public Administration in the Sphere of Ensuring Human Rights in the 
Conditions of Counteracting the Spread of the Covid-19 Pandemic, which should express a combination of normative (legal and international legal basis for regulating human and civil rights and freedoms); public management (management of the functioning of public power, structural features of the of public administration entities), socio-cultural (the state of the formed archetypes of health culture, the presence of safe living conditions) determinants of good governance. 
Ensuring the Human Rights and Freedoms in the Context of the Pandemic Covid-19

\section{REFERENCES}

Commissioner for Human Rights in St. Petersburg (2020). Global solidarity in the fight against coronavirus disease 2019 (Covid-19). In http://ombudsmanspb.ru/files/00002020/COVID_19/OON_Rezol_\%20Covid19.pdf.

Convention for the Protection of Human Rights and Fundamental Freedoms as amended by Protocols $n^{\circ} 11$ and 14 (1950).

Council of Europe. (2020). Adherence to democracy, the rule of law, and human rights during the sanitary crisis caused by Covid-19. In https://www.coe.int/en/web/congress/covid-19-toolkits.

European Centre for Disease Prevention and Control (2020). Data collected between 6:00 and 10:00 CET. (2020). In https://www.ecdc.europa.eu/en/geographicaldistribution-2019-ncov-cases.

Kivalov, S.V. (2019). Legal clinics as an important element of human right for free legal aid. Ius Humani 8, 169-186.

Legalhub (2020). The District Administrative Court of Kyiv has already received 22 lawsuits against the Government's decision on restrictions during quarantine. In https://legalhub.online/sudova-praktyka/do-oask-nadijshlo-vzhe-22-pozovyoskarzhennya-postanovy-uryadu-pro-obmezhennya-pid-chas-karantynu/.

Ukraine. (1993). Fundamentals of Ukrainian legislation on health care: Law. In https://zakon.rada.gov.ua/laws/show/2801-12.

Ukraine. (1994). On ensuring the sanitary and epidemic well-being of the population: Law 4004-XII. In https://zakon.rada.gov.ua/laws/show/4004-12.

Ukraine. (1996). Constitution of Ukraine. In https://zakon.rada.gov.ua/laws/show/254\%D0\%BA/96-\%D0\%B2\%D1\%80.

Ukraine. (1997). On local self-government in Ukraine: Law. In https://zakon.rada.gov.ua/laws/show/280/97-\%D0\%B2\%D1\%80.

Ukraine. (1999). On local state administrations: Law. In https://zakon.rada.gov.ua/laws/show/586-14.

Ukraine. (2020). On protection of the population from infectious diseases. Law 1645-III. In https://zakon.rada.gov.ua/laws/show/1645-14.

Ukraine. (2012). About administrative services: Law. In https://zakon.rada.gov.ua /laws/show/5203-17.

Ukraine. (2014). On the prevention of corruption: Law 1700-VII. In https://zakon.rada.gov.ua/laws/show/1700-18.

Ukraine. (2017). On amendments to the Commercial Procedural Code, the Civil Procedure Code, the Code of Administrative Procedure and other legislative acts: Law 2147-VIII. In https://zakon.rada.gov.ua/laws/show/2147-19.

Ukraine. (2017). On electronic trust services: Law 2155-VII. In https://zakon.rada.gov.ua /laws/show/2155-19. 
Serhii Kivalov

Ukraine. (2020) On amendments to some legislative acts of Ukraine aimed at providing additional social and economic guarantees in connection with the spread of coronavirus disease (Covid-19): Law 540-IX. In https://zakon.rada.gov.ua/laws/show/540-20.

Ukraine. (2020). On amendments to certain legislative acts of Ukraine aimed at preventing the occurrence and spread of coronavirus disease (Covid-19): Law 530-IX. In https://zakon.rada.gov.ua/laws/show/530-20.

Ukraine. (2020). On Amendments to the Law "On the State Budget of Ukraine for 2020." Law 553-IX. In https://zakon.rada.gov.ua/laws/show/553-20.

Ukraine. (2020). On amendments to the Procedure for working with technical means of videoconferencing during a court hearing in administrative, civil and commercial proceedings with the participation of the parties outside the courtroom: order of the State Judicial Administration of Ukraine from April 23, $2020, \mathrm{n}^{\circ} 196$. Unified state register of court decisions. In https://dsa.court.gov.ua/dsa/.

Ukraine. (2020). On the peculiarities of maintaining the Electronic Register of sick leaves to ensure information interaction of the electronic health care system with the Electronic Register of sick leaves: Resolution 159. In https://zakon.rada.gov.ua/laws/show/159-2020-\%D0\%BF.

Ukraine. (2020). On full general secondary education: Law 463-IX. In https://zakon.rada.gov.ua/laws/show/463-20.

Ukraine. Cabinet of Ministers (2010). On ensuring public participation in the formation and implementation of state policy: Resolution 996. In https://zakon.rada.gov.ua/laws/show/996-2010-\%D0\%BF.

Ukraine. Cabinet of Ministers. (2014). About the Cabinet of Ministers: Law. In https://zakon.rada.gov.ua/laws/show/794-18.

Ukraine. Cabinet of Ministers. (2014). Some issues of providing administrative services of executive bodies through the centers of providing administrative services: Order 523-r. In https://zakon.rada.gov.ua/laws/show/523-2014-\%D1\%80.

Ukraine. Cabinet of Ministers. (2015). On approval of the Regulation on the Ministry of Health: Resolution 267. In https://zakon.rada.gov.ua/laws/show/267-2015$\% \mathrm{D} 0 \% \mathrm{BF}$.

Ukraine. Cabinet of Ministers. (2019). On the implementation of an experimental project on the use of electronic student tickets: Resolution 1051. In https://zakon.rada.gov.ua/laws/show/1051-2019-\%D0\%BF.

Ukraine. Cabinet of Ministers. (2019). On the implementation of the pilot project on the use of electronic driver's license and electronic vehicle registration certificate: Resolution 956. In https://zakon.rada.gov.ua/laws/show/956-2019-\%D0\%BF.

Ukraine. Cabinet of Ministers. (2020). Analytical panels and open data. Covid-19. In https://covid19.gov.ua/analitichni-paneli-dashbordy.

Ukraine. Cabinet of Ministers. (2020). On establishing quarantine in order to prevent the spread of acute respiratory disease Covid-19 caused by coronavirus SARS-

Ius Humani | v. 9 (II) (2020), p. 22 
CoV-2 on the territory of Ukraine, and stages of mitigation of anti-epidemic measures: Resolution 392. In https://zakon.rada.gov.ua/laws/show/392-2020$\% \mathrm{D} 0 \% \mathrm{BF}$.

Ukraine. Cabinet of Ministers. (2020). On prevention of the spread on the territory of Ukraine of the acute respiratory disease Covid-19 caused by the coronavirus SARS-CoV-2: Resolution 211. In https://zakon.rada.gov.ua/laws/show/2112020-\%D0\%BF.

Ukraine. Cabinet of Ministers. (2020). On the implementation of a pilot project on the registration, re-registration of the unemployed and the appointment of unemployment benefits in electronic form: Resolution 307. (2020). In https://zakon.rada.gov.ua/laws/show/307-2020-\%D0\%B..F.

Ukraine. Cabinet of Ministers. (2020). On the implementation of a pilot project on the use of electronic display of information contained in the passport of a citizen of Ukraine in the form of a card, and electronic display of information contained in the passport of a citizen of Ukraine for travel abroad: Resolution 278. In https://zakon.rada.gov.ua/laws/show/278-2020-\%D0\%BF.

Ukraine. Cabinet of Ministers. (2020). Some issues of appointment to civil service positions for the period of quarantine established to prevent the spread of acute respiratory disease Covid-19 caused by coronavirus SARS-CoV-2 in Ukraine: Resolution 290. In https://zakon.rada.gov.ua/laws/show/290-2020-\%D0\%BF.

Ukraine. Cabinet of Ministers. (December 27, 2017). Regulations on the National Health Service of Ukraine. In https://zakon.rada.gov.ua/laws/show/1101-2017$\% \mathrm{D} 0 \% \mathrm{BF}$.

Ukraine. Judicial Power. (2020). The District Administrative Court of Kyiv is challenging the restrictions imposed by the Government on the movement of persons from 6 to 24 April 2020. In https://court.gov.ua/press/news/920885/.

Ukraine. Ministry of Health. (2015). Official site. In http://moz.gov.ua.

Ukraine. Ministry of Health. (2020). Organization of medical care for patients with coronavirus disease (Covid-19): Order 722. In https://zakon.rada.gov.ua/rada/show/v0722282-20\# n65.

United Nations. (1948). Universal Declaration of Human Rights. In https://www.un.org/en/universal-declaration-human-rights/.

United Nations. (2019). Political declaration of the high-level meeting on universal health coverage. In https://undocs.org/en/A/RES/74/2.

World Health Organization. (2020a). Official website. In https://www.who.int/home.

World Health Organization. (2020b). Updated strategy to combat Covid-19. In https://www.who.int/docs/default-source/coronaviruse/covid19-strategyupdate-2020-ru.pdf?sfvrsn=29da3ba0_19.

World Health Organization. (2005, May 23). International Health Regulations: World Health Organization Rules. In https://zakon.rada.gov.ua/laws/show/897_007. 